Contributions:

A Study design/planning

B Data collection/entry

C Data analysis/statistics

D Data interpretation

E Preparation of manuscript

F Literature analysis/search

$\mathrm{G}$ Funds collection

\title{
EVALUATION OF THE FREQUENCY FOLLOWING RESPONSE IN ITALIAN CHILDREN: A PILOT STUDY
}

\author{
Milaine Dominici Sanfins ${ }^{1 A B D E F}$, Stavros Hatzopoulos ${ }^{2 A C D E}$, \\ Thais Antonelli Diniz Hein ${ }^{1 \mathrm{~B}}$, Tatiana Bordin ${ }^{3 \mathrm{D}}$, Piotr H. Skarzynski ${ }^{4,5,6 \mathrm{DEG}}$, \\ Maria Francisca Colella-Santos ${ }^{1 \mathrm{DEG}}$ \\ ${ }^{1}$ Child and Adolescent Health Graduate Program, Faculty of Medical Sciences, \\ State University of Campinas, Campinas, São Paulo, Brazil \\ ${ }^{2}$ Audiology and ENT Clinic, University of Ferrara - UNIFE, Ferrara, Italy \\ ${ }^{3}$ Eldorado Institute, Campinas, São Paulo, Brazil \\ ${ }^{4}$ World Hearing Center, Warsaw, Poland \\ ${ }^{5}$ Department of Heart Failure and Cardiac Rehabilitation, Medical University of Warsaw, \\ Warsaw, Poland \\ ${ }^{6}$ Institute of Sensory Organs, Kajetany, Poland
}

Corresponding author: Stavros Hatzopoulos, Clinic of Audiology and ENT, University of Ferrara, Ferrara, 44100, Italy, e-mail : sdh1@unife.it

\begin{abstract}
Background: Speech-ABR is an electrophysiological procedure that makes it possible to monitor the processing of auditory information in the subcortical region, easily and quickly, applicable even to very young subjects. So far there are no data in the literature describing the standards of normality of FFR in Italian children and adolescents. So the objective of the study was to assess the FFR in Italian children and adolescents with normal hearing.

Methods: Twenty-four children and young adolescents, 12 female and 12 male, participated in the study. Their age ranged from 9 to 14 years (average 11.8 years). All subjects were Italian native speakers, right handed and with normal hearing. All subjects had normal behavioral and electrophysiological hearing thresholds. The speech-ABR recordings were acquired by a Biologic Navigator Pro (Natus, USA) with BioMark software.

Results: The analysis for absolute latency of speech sounds (specifically for the syllable/da/) gave: latency (ms) (male/female) wave V (6.57/6.41), wave A (7.49/7.54), wave C (18.34/18.57), wave D (22.07/22.22), wave E (30.74/30.50), wave F (39.12/39.19), and wave O (48.06/47.88). For amplitude $(\mu \mathrm{V})$, the responses were: (male/female) wave $\mathrm{V}(0.10 / 0.11)$, wave $\mathrm{A}(0.21 / 0.22)$, wave $\mathrm{C}(0.11 / 0.11)$, wave $\mathrm{D}(0.12 / 0.13)$, wave $\mathrm{E}$ $(0.19 / 0.24)$, wave F (0.22/0.21), and wave O (0.18/0.09). Complex VA: Slope (male/female), 0.33/0.30; Area (male/female), 0.28/0.37.
\end{abstract}

Conclusions: We found different FFR profiles in the 24 children to those reported in the literature in adult subjects.

Key words: FFR • speech perception • electrophysiology

\section{EVALUACIÓN DE POTENCIAL EVOCADO AUDITIVO DE SEGUIMIENTO (PEA-S) EN LOS NIÑOS ITALIANOS: ESTUDIO PILOTO}

\section{Resumen}

Introducción: Speech-ABR es un procedimiento electrofisiológico que permite monitorizar el procesamiento de la información auditiva en la región subcortical de una manera fácil y rápida, incluso en los pacientes muy jóvenes. Hasta el momento, no hay datos en la literatura que describa los estándares de PEA-S en niños y adolescentes italianos. El objetivo del estudio fue evaluar la FFR en niños y adolescentes italianos con audición normal.

Métodos: En el estudio participaron 24 niños y adolescentes, 12 mujeres y 12 hombres. Su edad osciló entre los 9 y 14 años (media de 11.8 años). Todos los sujetos eran hablantes nativos de la lengua italiana, diestros, con audición normal. Todos los sujetos tenían umbrales conductuales y electrofisiológicos normales. Los registros de Speech-ABR se han registrado utilizando Biologic Navigator Pro (Natus, EE. UU.), con el software BioMark.

Resultados: Los resultados del análisis para una latencia absoluta de los sonidos del habla, más precisamente para la sílaba / da /: latencia (ms) (hombre / mujer) onda V (6.57 / 6.41), onda A (7.49 / 7.54) onda C (18.34 / 18.57), onda D (22.07 / 22.22), onda E (30.74 / 30, 50), onda F (39.12 / 39.19) y onda O (48.06 / 47.88) Para la amplitud $(\mu \mathrm{V})$ las respuestas fueron las siguientes: (masculina / femenina) onda V (0.10 / $0.11)$, onda A $(0.21 / 0.22)$, onda C ( $0.11 / 0.11)$, onda D $(0.12 / 0.13)$, onda E $(0,19 / 0.24)$, onda F $(0.22 / 0.21)$ y onda O (0, 18 / 0.09$)$. Complejo VA - pendiente (masculino / femenino): (0.33 / 0.30) y área (masculino / femenino): $(0.28$ / 0.37).

Conclusiones: Se encontraron diferentes perfiles de FFR en los 24 niños, que difieren de los descritos para adultos en la literatura.

Palabras clave: niños italianos • FFR • percepción del habla • electrofisiología. 


\title{
ОЦЕНКА ПОТЕНЦИАЛОВ, ВОСПРОИЗВОДЯЩИХ ЧАСТОТУ (FFR) У ИТАЛЬЯНСКИХ ДЕТЕЙ: ПИЛОТНОЕ ИССЛЕДОВАНИЕ
}

\begin{abstract}
Аннотация
Введение: КСВП речи - это электрофизиологическая процедура, которая позволяет легко и быстро наблюдать за процессом обработки слуховой информации в подкорковой области даже у очень маленьких пациентов. До настоящего времени в литературе отсутствуют данные, описывающие стандарты норм FFR у итальянских детей и подростков. Целью исследования явлется оценка FFR у итальянских детей и подростков с нормальным слухом.

Методы: В исследовании приняло участие 24 ребенка и подростка, из которых было 12 девочек и 12 мальчиков. Их возраст колебался от 9 до 14 лет (средний 11,8 лет). Все обследуемые были носителями итальянского языка, правши, с нормальным слухом. Все обследуемые имели нормальные поведенческие и электрофизиологические пороги. Записи КСВП речи были зарегистрированы с помощью Biologic Navigator Pro (Natus, CША) с программным обеспечением BioMark.

Результаты: Результаты анализа абсолютной латенции в диапазоне речевых звуков, точнее для слога /da/: латенция (ms) (мужской пол/ женский пол) волна V (6,57 / 6,41), волна A $(7,49$ / 7,54), волна С $(18,34$ / 18,57), волна D (22,07 / 22,22), волна Е $(30,74$ / 30,50), волна F $(39,12$ / 39,19) и волна O $(48,06$ / 47,88) Для амплитуды (мкВ) были получены следующие ответы: (мужской пол/ женский пол) волна V $(0,10 / 0,11)$, волна A $(0,21 / 0,22)$, волна C $(0,11 / 0,11)$, волна D $(0,12$ / 0,13), волна E $(0,19$ / 0,24), волна F $(0,22$ / 0,21) и волна O $(0,18$ / 0,09). Комплекс VA: отклонение (мужской пол/ женский пол): $(0,33$ / 0,30) и область (мужской пол/ женский пол): $(0,28 / 0,37)$.
\end{abstract}

Выводы: В случае 24 детей были обнаружены профили FFR, отличающиеся от результатов взрослых, описанных на данный момент в литературе.

Ключевые слова: итальянские дети • FFR • восприятие речи • электрофизиология

\section{OCENA CZĘSTOTLIWOŚCIOWEJ ODPOWIEDZI WYWOŁANEJ U WŁOSKICH DZIECI: BADANIE PILOTAŻOWE}

\section{Streszczenie}

Wstęp: ABR mowy jest procedurą elektrofizjologiczną, która umożliwia monitorowanie przetwarzania informacji słuchowej w rejonie podkorowym, w łatwy i szybki sposób, nawet w przypadku bardzo młodych pacjentów. Jak dotąd w literaturze nie ma danych opisujących standardy norm FFR u włoskich dzieci i młodzieży. Celem badania była ocena FFR u włoskich dzieci i młodzieży z prawidłowym słuchem.

Metody: W badaniu wzięło udział 24 dzieci i natolatków, 12 płci żeńskiej i 12 płci męskiej. Ich wiek wahał się od 9 do 14 lat (średnia 11,8 lat). Wszyscy badani byli rodzimymi użytkownikami języka włoskiego, praworęczni, z normalnym słuchem. Wszyscy badani mieli normalne progi behawioralne i elektrofizjologiczne. Zapisy ABR mowy zostały zarejestrowane za pomocą Biologic Navigator Pro (Natus, USA) - z oprogramowaniem BioMark.

Wyniki: Wyniki analizy bezwzględnej latencji dźwięków mowy, a dokładniej dla sylaby /da/: latencja (ms) (mężczyzna / kobieta) fala V (6,57 / 6,41), fala A $(7,49$ / 7,54), fala C $(18,34$ / 18,57), fala D $(22,07$ / 22,22), fala E $(30,74$ / 30, 50), fala F $(39,12$ / 39,19) i fala O $(48,06$ / 47,88) Dla amplitudy $(\mu \mathrm{V})$ odpowiedzi były nastepujące: (mężczyzna / kobieta) fala $\mathrm{V}(0,10 / 0,11)$, fala A $(0,21 / 0,22)$, fala C $(0,11 / 0,11)$, fala $\mathrm{D}$ $(0,12$ / 0,13), fala E $(0,19 / 0,24)$, fala F $(0,22$ / 0,21) i fala O $(0,18$ / 0,09). Kompleks VA - nachylenie (mężczyzna / kobieta): $(0,33$ / 0,30) i obszar (mężczyzna / kobieta): $(0,28$ / 0,37).

Wnioski: U 24 dzieci wykryto profile FFR różniące się od tych dla osób dorosłych opisywanych dotąd w literaturze.

Słowa kluczowe: włoskie dzieci • FFR • percepcja mowy • elektrofizjologia

\section{Introduction}

The electrophysiological assessment of the auditory pathways allows us to have a better understanding of the mechanisms involved in the perception of acoustic stimuli (1). Different electrophysiological protocols are used in the assessment of the auditory periphery, brainstem and auditory cortex. Recently, auditory brainstem responses have been elicited by human speech stimuli, in order to study the mechanisms and pathways of the auditory subcortical stimulation (2-5). These responses can be considered as a discrete biological marker and they can discriminate healthy individuals from those presenting various types of hearing pathologies. Protocols based the frequency following response (FFR) can be applied to all subjects, even to young children at preschool age $(2,3,6-10)$.
The stimulus template was developed by Kraus et al. at Northwestern University (5). From the large family of possible complex speech stimuli, the syllable /da/ has been the most widely used (10). The stimulus consists of two parts: the consonant /d/ (transient portion or onset) and the short vowel /a/ (sustained portion or following frequency response). Upon stimulation with the syllable /da/, the subcortical electrophysiological response emerges as a waveform composed by seven distinct wave peaks termed as: $\mathrm{V}, \mathrm{A}, \mathrm{C}, \mathrm{D}, \mathrm{E}, \mathrm{F}$, and $\mathrm{O}$. Waves $\mathrm{V}$ and $\mathrm{A}$ reflect the onset of the response (called also VA complex), wave $\mathrm{C}$ the transition region, waves $\mathrm{D}, \mathrm{E}$ and $\mathrm{F}$ the periodic region (the frequency following response), and wave $\mathrm{O}$ the offset of the response $(2,3,5,11)$. A typical FFR response is shown in Figure 1.

Italian is the official language in Italy and San Marino, and one of the official languages of Switzerland. The presence 
of the Italian language, mostly northern Italian dialects, is abundant in Brazil, Argentina and Uruguay. In these countries, Spanish and Portuguese were influenced by Italian (12).

FFR is an electrophysiological procedure that makes it possible to monitor the processing of auditory information in the subcortical region, in an easy and fast manner, applicable even to very young subjects. So far there are no data in the literature describing FFR responses in Italian children and adolescents. In this context, the objective of the study was to assess the FFR characteristics in Italian children and adolescents with normal hearing.

\section{Methods}

\section{Ethics statement}

This study was approved by the University of Ferrara, Ethics in Research Committee, under protocol number 160387. Data were collected from March to June 2016 at the Audiology \& ENT Clinic of Ferrara University. Written informed consent was obtained from the parents of all the participating children prior to data collection.

\section{Participants}

Twenty-four children / young adolescents, 12 female and 12 male, participated in the study. Their age ranged from 9 to 14 years (average $11.83 \mathrm{y}$ ). All subjects were Italian native speakers, right handed and with a normal hearing.

All participated subjects passed the following inclusion criteria:

- A hearing threshold $<15 \mathrm{~dB}$ HL (250 to $8000 \mathrm{~Hz})$ (13);

- A type A tympanogram with a presence of ipsilateral and contralateral acoustic reflexes $(500$ to $4000 \mathrm{~Hz})$, in both ears $(13,14)$;

- A normal response $\geq 95 \%$ to the dichotic digits test, a central auditory processing testing procedure (15);

- A normal click auditory brainstem response (ABR) with waves I, III and V present and with an inter-peak interval I-III, III-V and I-V within normal latency standards (I: 1.54; III: 3.67; V: 5.52; I-III: 2.13; III-V: 1.85; I-V: $3.98 \mathrm{~ms}$ )

- No history of neurological disorders;

- No language or learning complaints. This information was provided by the subject's parents and teachers.

\section{Procedures}

The electrophysiological evaluation was conducted using the Biologic Navigator Pro apparatus (Natus, USA). All FFR responses were recorded in a sound-attenuated and electrically shielded room, where subjects passively sat comfortably on a reclining chair. Prior to the ABR recording, skin cleaning was performed at each spot where the electrodes were to be fixed. Electrodes were then dipped in a conductive paste and then placed on skin with the help of adherent paste. These procedures ensured good impedance between skin and electrodes.

FFR responses were collected using one channel with the surface electrodes fixed according to the $10-20$ positioning

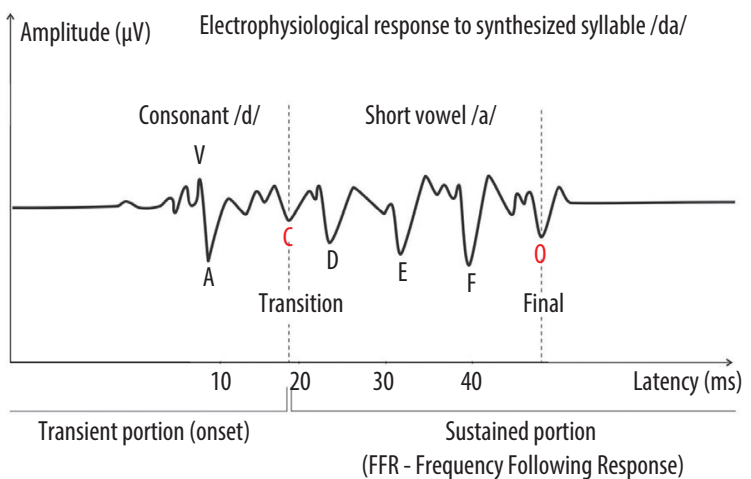

Figure 1: Typical FFR response (10) showing the time location (latency) of the seven FFR waves

system: the active electrode was positioned at the vertex $(\mathrm{Cz})$, the reference electrode at the ipsilateral mastoid and the ground at the contralateral mastoid (16). Automatic switching function of reference signals and the amplifier ground based on the stimulated ear was activated on the equipment. The electrode from the left ear was connected to input 2 channel 1 and the electrode from the right ear was connected to ground connection cable. During the recording session, impedance was maintained at below $5 \mathrm{k} \Omega$ and inter-electrode impedance below $3 \mathrm{k} \Omega$.

During the evaluation, participants were asked to keep their eyes closed in order to avoid eye movement artifacts. Also, changes in subject's position (by changing the chair's recline angles) were tested for those who showed myogenic artifacts, with the purpose of establishing the best recording conditions. The order of the ear tested was randomized across subjects.

The FFR responses were elicited using a $40 \mathrm{~ms}$ synthetic speech syllable /da/, provided by the BioMARK software module of the Biologic Navigator Pro apparatus. An alternating polarity stimulus was presented monaurally to the right ear through the Biologic ER-3A insert earphones, with a repetition rate of $10.9 / \mathrm{s}$ and an intensity of $80 \mathrm{~dB}$ SPL. Two blocks of 3000 artifact-free sweeps were collected. These were summed and the averaged wave peaks were identified and analyzed. Stimuli of alternative polarities were used in order to isolate the neural responses from the cochlear microphonic and to reduce the influence of stimulus artifacts (17) A time window of $85.33 \mathrm{~ms}$ (including $15 \mathrm{~ms}$ of pre-stimulus time) and online filter setting of $100-2000 \mathrm{~Hz}$ were used. Recordings with more than $10 \%$ sweeps rejected as artifact, were repeated to obtain a reliable response with less artifact contamination.

All analyses were conducted offline and the waves were visually identified and manually marked. The initial latency values of the seven waves $(\mathrm{V}, \mathrm{A}, \mathrm{C}, \mathrm{D}, \mathrm{E}, \mathrm{F}$ and $\mathrm{O}$ ) were based on analysis criteria from previously published studies $(2-6,11,18,19)$. The analyses were focused on four major elements: the onset portion or early vocalization (the consonant portion represented by waves $\mathrm{V}$ and $\mathrm{A}$ or by the so called complex VA), the transition period between the consonant and vowel (wave C), the sustained portion / FFR - vowel (Waves D, E, F) and the offset portion or 
Table 1. Latencies and amplitudes (means and standard deviations) of FFR responses in male and female subjects

\begin{tabular}{|c|c|c|c|c|c|c|c|c|c|c|c|c|c|c|c|c|}
\hline \multirow{3}{*}{ Gender } & \multicolumn{4}{|c|}{ v } & \multicolumn{4}{|c|}{ A } & \multicolumn{4}{|c|}{ C } & \multicolumn{4}{|c|}{ D } \\
\hline & \multicolumn{2}{|c|}{ Lat (ms) } & \multicolumn{2}{|c|}{$A m p(m V)$} & \multicolumn{2}{|c|}{ Lat (ms) } & \multicolumn{2}{|c|}{$A m p(m V)$} & \multicolumn{2}{|c|}{ Lat (ms) } & \multicolumn{2}{|c|}{$A m p(m V)$} & \multicolumn{2}{|c|}{ Lat (ms) } & \multicolumn{2}{|c|}{$A m p(m V)$} \\
\hline & $M$ & SD & $M$ & SD & $M$ & SD & $M$ & SD & $M$ & SD & $M$ & SD & $M$ & SD & $M$ & SD \\
\hline Male & 6.57 & 0.23 & 0.10 & 0.05 & 7.49 & 0.33 & 0.21 & 0.05 & 18.34 & 0.34 & 0.11 & 0.11 & 22.07 & 0.32 & 0.12 & 0.07 \\
\hline Female & 6.41 & 0.28 & 0.11 & 0.05 & 7.54 & 0.27 & 0.22 & 0.05 & 18.57 & 0.44 & 0.11 & 0.10 & 22.22 & 0.31 & 0.13 & 0.08 \\
\hline
\end{tabular}

\begin{tabular}{|c|c|c|c|c|c|c|c|c|c|c|c|c|}
\hline \multirow{3}{*}{ Gender } & \multicolumn{4}{|c|}{$\mathbf{E}$} & \multicolumn{4}{|c|}{$\mathbf{F}$} & \multicolumn{4}{|c|}{0} \\
\hline & \multicolumn{2}{|c|}{ Lat (ms) } & \multicolumn{2}{|c|}{$A m p(m V)$} & \multicolumn{2}{|c|}{ Lat (ms) } & \multicolumn{2}{|c|}{ Amp (mV) } & \multicolumn{2}{|c|}{ Lat (ms) } & \multicolumn{2}{|c|}{$A m p(m V)$} \\
\hline & $M$ & SD & $M$ & SD & $M$ & SD & $M$ & SD & $M$ & SD & $M$ & SD \\
\hline Male & 30.74 & 0.54 & 0.19 & 0.05 & 39.12 & 0.29 & 0.22 & 0.08 & 48.06 & 0.81 & $0.18^{*}$ & 0.09 \\
\hline Female & 30.50 & 0.53 & 0.24 & 0.09 & 39.19 & 0.30 & 0.21 & 0.10 & 47.88 & 0.49 & $0.09^{*}$ & 0.05 \\
\hline
\end{tabular}

Key: M, mean; SD, standard deviation; Lat, latency; Amp, amplitude.

The * symbol indicates a significant difference at $p<0.05$

Table 2. VA measures of FFR responses between genders - slope and area under the curve (mean and standard deviation). No significant differences were observed at $p<0.05$

\begin{tabular}{lcccc}
\hline \multirow{2}{*}{ Gender } & \multicolumn{2}{c}{ Slope VA $(\mu \mathrm{V} / \mathrm{ms})$} & \multicolumn{2}{l}{ Area VA $(\mu \mathrm{V} \times \mathrm{ms})$} \\
& Value & SD & Value & SD \\
\hline Male & 0.33 & 0.09 & 0.28 & 0.09 \\
\hline Female & 0.30 & 0.09 & 0.37 & 0.12 \\
\hline
\end{tabular}

the end of vocalization - vowel (wave O). The first step of the analyses was to identify the onset portion of the response with latency values less than $10 \mathrm{~ms}$. The onset portion of the response consists of a positive peak (wave V) followed by a negative peak (wave A). In a second step, the waves $\mathrm{C}, \mathrm{D}, \mathrm{E}, \mathrm{F}$ and $\mathrm{O}$ were identified, which present negative peaks $(5,11,20)$. The VA complex (component of the onset response) was investigated by its slope ( $\mu \mathrm{v} / \mathrm{ms}$ ) and by its area under the slope ( $\mu \mathrm{v} \mathrm{x} \mathrm{ms}$ ) measures. Visual representations of FFR responses can be found in previous publications $(2,10)$.

\section{Statistical analyses}

The data were explored with the standard statistical tools (i.e. means, distributions of the means, histograms etc). The Shapiro-Wilk procedure was used to evaluate the normality of the data distributions. Mean gender differences were explored with an analysis of variance (ANOVA) procedure, under the assumption that the data were normally distributed. The sample size was estimated by previous sample data using an acceptable error estimate of 0.2. All statistical analyses were conducted using the R-project software (www.r-project.org) with a level of significance of $5 \%(p \leq 0.05)$.

\section{Results}

\section{Latency}

The data showed that the male subjects have reduced mean latency values in relation to the female subjects, in the following components: wave A, wave C, wave D and wave $\mathrm{F}$. The female subjects have reduced latency values in the following components: wave $\mathrm{V}$, wave $\mathrm{E}$ and wave $\mathrm{O}$. The greatest difference in latency values between the two groups was observed in the wave E. These differences were not statistically significant.

These results are summarized in Table 1 .

\section{Amplitude}

In terms of wave amplitude values for the majority of components (wave V, A, D, and E) the female subjects presented higher averages in comparison to the male FFR responses: The latter presented higher averages for waves $\mathrm{F}$ and $\mathrm{O}$. The greatest difference in amplitude values was observed at the wave $\mathrm{O}$ and it was the only difference which was found statistically significant. The results are summarized in Table 1. The Analytical ANOVA results are presented in Table 3.

\section{Complex VA}

Results from the complex VA show that the male subjects presented higher averages, across the 7 waves, for the slope component of the VA complex. The female subjects presented higher responses in the area component of the VA complex. The data did not indicate any significant differences. The results are summarized in Table 2.

\section{Discussion}

The objective of the study was to assess the characteristics of the Frequency Following Responses in normacusic Italian children and adolescents.

In this study FFR data were acquired from twenty-four children and young adolescents who were Italian native speakers. Their age ranged from 8 to 14 years. The male subjects had an average age of $11.7 \mathrm{y}$ and the female subjects an average age of $12 \mathrm{y}$. We have found different FFR profiles to those reported in the literature specially from adult subjects $(9,20,21)$. The male subjects showed faster 
Sanfins M. D. et al. - Evaluation of the frequency following response...

Table 3. Analytical ANOVA data per wave (variables = latency and amplitude). The only significant gender difference (indicated by ${ }^{* \star}$ ) was observed for the amplitude of wave O. Level of significance $p<0.05$

\begin{tabular}{|c|c|c|c|c|}
\hline & Sum Sq & Mean Sq & F value & $\operatorname{Pr}(>F)$ \\
\hline V_latency & 0.1411 & 0.14107 & 2.144 & 0.157 \\
\hline V_amplitude & 0.0024 & 0.0024 & 1.078 & 0.310 \\
\hline A_latency & 0.0171 & 0.01707 & 0.183 & 0.673 \\
\hline A_amplitude & 0.00004 & 0.0000375 & 0.014 & 0.906 \\
\hline C_latency & 0.308 & 0.3083 & 2.008 & 0.170 \\
\hline C_amplitude & 0.0002 & 0.000204 & 0.017 & 0.898 \\
\hline D_latency & 0.1247 & 0.1247 & 1.242 & 0.277 \\
\hline D_ampitude & 0.00027 & 0.000267 & 0.045 & 0.834 \\
\hline E_latency & 0.353 & 0.35281 & 0.215 & 0.282 \\
\hline E_amplitude & 0.01354 & 0.013538 & 2.368 & 0.138 \\
\hline F_latency & 0.0294 & 0.0294 & 0.335 & 0.569 \\
\hline F_amplitude & 0.00082 & 0.000817 & 0.096 & 0.760 \\
\hline O_latency & 0.18 & 0.1803 & 0.4 & 0.534 \\
\hline O_amplitude & 0.04335 & 0.04335 & 7.543 & $0.0118^{\star *}$ \\
\hline
\end{tabular}

FFR responses, that is, the appearance of the waves occurred at smaller latencies for waves A, D, and F and for the VA slope. In contrast, the female subjects presented faster responses (shorter latencies) for the V, C, E, and $\mathrm{O}$ waves, and in VA area. The mean amplitude of the $\mathrm{C}$ wave was found similar across genders. The only significant difference between genders was observed for wave $\mathrm{O}$, which was also accompanied by large $\mathrm{SD}$ values of the male FFR responses. The high SD values can be interpreted as a sign of a non-very homogenous sample, suggesting the need of a greater sample size in any future FFR studies on Italian speakers.

The data of this study do not corroborate with the data of Krizman et al. (21), who has reported that there is a difference between responses of adult female subjects (with lower latency values and higher amplitude values) and adult male subjects in the transient portion of the FFR. A possible explanation of why the data of this study do not show any extensive gender effects could be the fact that the auditory functions responsible for the codification of speech stimuli in children and adolescents continue to mature towards adulthood. This is supported by data presented from Skoe et al. (22) showing that the speech ABR response evolves and matures from the period of childhood to adulthood.

\section{References}

1. Sanfins M. Auditory neuropathy/auditory dys-synchrony: a study with the hearing impaired students of three special schools in the city of São Paulo. São Paulo: University of São Paulo; 2004.
The current pilot study is probably limited by errors induced by the used sample size and the homogeneity of the observed FFR responses. The sample size was estimated by previously unpublished data and based on the average latency variability of the observed 7 waves in the FFR response, assuming an acceptable error of 0.20 . A better approach would be to consider the individual variability of each wave and to optimize the sample accordingly. For example, to fully optimize wave C, according the present data, 80 female and 109 male subjects would be necessary. Such a task was impossible for the time frame of the pilot project. In this context, it is necessary to consider that the sampling-induced error is also common in the majority of previous FFR studies, since the published data are derived from smaller samples, comparable to the one used in the present study.

\section{Conclusion}

FFR is an electrophysiological procedure that makes it possible to monitor the processing of auditory information in the subcortical region applicable even to very young subjects. So far there are no data in the literature describing the FFR characteristics in Italian children and adolescents. The present data suggest that there are no gender differences across the FFR waves, except for wave O.
2. Sanfins MD, Borges LR, Ubiali T, Donadon C, Hein TAD, Hatzopoulos S, et al. Speech-evoked brainstem response in normal adolescent and children speakers of Brazilian Portuguese. Int J Ped Otorhinolaryngol, 2016: 12-9. 
3. Sanfins M, Borges L, Ubiali T, Colella-Santos M. Speech-evoked auditory brainstem response in the differential diagnosis of scholastic difficulties. Braz J Otorhinolaryngol, 2017; 83(1): 112-6.

4. Karawani H, Banai K. Speech-evoked brainstem responses in Arabic and Hebrew speakers. Int J Audiol, 2010; 49(11): 844-9.

5. Skoe E, Kraus N. Auditory brainstem response to complex sounds: a tutorial. Ear Hear, 2010; 31: 320-24.

6. Sinha SK, Basavaraj V. Speech evoked auditory brainstem responses: a new tool to study brainstem encoding of speech sounds. Indian J Otolaryngol Head Neck Surg, 2010; 62(4): 395-9.

7. Tahaei AA, Ashayeri H, Pourbakht A, Kamali M. Speech evoked auditory brainstem response in stuttering. Scientifica (Cairo), 2014; 2014: 328646.

8. Wible B, Nicol T, Kraus N. Atypical brainstem representation of onset and formant structure of speech sounds in children with language-based learning problems. Biol Psychol, 2004; 67(3): 299-317.

9. Vander Werff KR, Burns KS. Brain stem responses to speech in younger and older adults. Ear Hear, 2011; 32(2): 168-80.

10. Sanfins M, Colella-Santos M. A review of the clinical applicability of speech-evoked auditory brainstem responses. J Hear Sci, 2016; 6(1): 9-16.

11. Johnson KL, Nicol TG, Kraus N. Brain stem response to speech: a biological marker of auditory processing. Ear Hear, 2005; 26(5): 424-34.

12. Wikipédia Língua Italiana. https://pt.wikipedia.org/wiki/ L\%C3\%ADngua_italiana; [Available from: https://pt.wikipedia. org/wiki/L\%C3\%ADngua_italiana]
13. Northern J, Downs M. Avaliação auditiva comportamental. In: Northern J, Downs M, editors. Audição na infância. Rio de Janeiro: Guanabara-Koogan; 2005. p. 129-67.

14. Jerger J. Clinical experience with impedance audiometry. Arch Otolaryngol, 1970; 92(4): 311-24.

15. Musiek F, Gollegly K, Kibbe K, Verkest-Lenz S. Proposed screening test for central auditory disorders: follow-up on dichotic digits test. Am J Otol, 1991; 12: 109-13.

16. Jasper H. The Ten-Twenty system of the International Federation. Electroenceph Clin Neurophysiol, 1958; 10: 371-5.

17. Gorga M, Abbas P, Worthington D. Stimulus calibration in ABR measurements. In: Jacobson J, ed. The Auditory Brainstem Response. San Diego: College Hill Press; 1985.

18. Song JH, Banai K, Russo NM, Kraus N. On the relationship between speech- and nonspeech-evoked auditory brainstem responses. Audiol Neurotol, 2006; 11(4): 233-41.

19. Hornickel J, Knowles E, Kraus N. Test-retest consistency of speech-evoked auditory brainstem responses in typically-developing children. Hear Res, 2012; 284(1-2): 52-8.

20. Russo N, Nicol T, Musacchia G, Kraus N. Brainstem responses to speech syllables. Clin Neurophysiol, 2004; 115: 2021-30.

21. Krizman J, Skoe E, Kraus N. Sex differences in auditory subcortical function. Clin Neurophysiol, 2012; 123(3): 590-7.

22. Skoe E, Krizman J, Anderson S, Kraus N. Stability and plasticity of auditory brainstem function across the lifespan. Cerebral Cortex, 2015; 25(6): 1415-26. 